\title{
A Comparison of Ondansetron, Palonosetron and Granisetron for Prevention of Post-Operative Nausea and Vomiting after Laparoscopic Surgeries
}

\author{
Ruchika Kathuria1, Pranav Bansal2, Meena Singh³, Sumitra Kanojiya4, Vibha Mehta5, Geetika Duggal6, Sunil Sorout7 , \\ Akanksha Mishra ${ }^{8}$

\begin{abstract}
${ }^{1}$ Department of Anaesthesiology and Critical Care, Maharaja Agrasen Medical College, Agroha, Haryana, India. ${ }^{2}$ Department of Anaesthesiology and Critical Care, BPS Government Medical College for Women, Khanpur, Haryana, India. ${ }^{3}$ Department of Anaesthesiology and Critical Care, BPS Government Medical

Agrasen Medical College, Agroha, Haryana, India. ${ }^{5}$ Department of Anaesthesiology and Critical Care, Maharaja Agrasen Medical College, Agroha, Haryana, India. ${ }^{6}$ Department of Anaesthesiology and Critical Care, Maharaja Agrasen Medical College, Agroha, Haryana, India. ${ }^{7}$ Department of Anaesthesiology and Critical Care, Maharaja Agrasen Medical College, Agroha, Haryana, India. ${ }^{8}$ Department of Anaesthesiology and Critical Care, BPS Government Medical College for Women, Khanpur, Haryana, India.
\end{abstract} \\ College for Women, Khanpur, Haryana, India. ${ }^{4}$ Department of Anaesthesiology and Critical Care, Maharaja
}

\section{ABSTRACT}

\section{BACKGROUND}

Post-Operative Nausea and Vomiting (PONV) "the little big problem" after surgery/anaesthesia is a common side-effect which compromises the quality of care, delays discharge and thereby delays resumption of activities of daily living. A number of pharmacological agents (antihistamines, butyrophenones, dopamine receptor antagonists) have been used, and the 5-hydroxytryptamine type 3 receptor antagonists have been found to be effective in prevention and treatment of PONV. Thus, we compared the prophylactic effects of intravenously administered ondansetron, palonosetron, and granisetron in prevention of postoperative nausea and vomiting in patients undergoing laparoscopic surgery under general anaesthesia.

\section{METHODS}

This prospective, double blind study, comprising of 135 patients of ASA physical status I and II of either gender, was carried out after approval was obtained from the Institutional Ethical and Scientific Committee. Patients were randomized into three equal groups. Group P received inj. palonosetron $(0.075 \mathrm{mg})$, group 0 received inj. ondansetron (8 mg), and group $G$ received inj. granisetron (2.5 mg) intravenously five minutes before induction of anaesthesia. The episodes of postoperative nausea and vomiting, severity of nausea, need for rescue antiemetic, side effects and patient satisfaction were observed in the study groups for 24 hours in the post-operative period. At the end of study, results were compiled, and statistical analysis was done using ANOVA, chi-square test, and Kruskal Wallis Test. Value of $\mathrm{p}<0.05$ was considered significant.

\section{RESULTS}

The incidence of PONV was significantly less in the palonosetron group (95.6\%) as compared to the ondansetron group (80\%) and granisetron group (73.3\%), with a lesser need for rescue antiemetic in the palonosetron group. All the three study groups did not have significant adverse effects reflecting that all the three drugs were well-tolerated. Patient satisfaction score was also more with palonosetron.

\section{CONCLUSIONS}

Palonosetron was more effective in prevention of PONV after anaesthesia due to its prolonged duration of action than ondansetron and granisetron.

\section{KEY WORDS}

Granisetron, Ondansetron, Palonosetron, Laparoscopy, Post-Operative Nausea and Vomiting (PONV)

\author{
Corresponding Author: \\ Dr. Ruchika Kathuria, \\ House No. 505, P. L. A, Near Town Park, \\ Near Gymkhana Club, Hisar, \\ Haryana, India. \\ E-mail: ruchikakathuria15@gmail.com
}

DOI: 10.14260/jemds/2020/35

Financial or Other Competing Interests: None.

How to Cite This Article:

Kathuria R, Bansal P, Singh $M$, et al. A comparison of ondansetron, palonosetron and granisetron for prevention of post operative nausea and vomiting after laparoscopic surgeries. J. Evolution Med. Dent. Sci. 2020;9(03):157-161, DOI: 10.14260/jemds/2020/35

Submission 20-11-2019,

Peer Review 01-01-2020,

Acceptance 08-01-2020,

Published 20-01-2020.

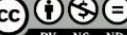




\section{BACKGROUND}

Post-Operative Nausea and Vomiting (PONV) is a commonly encountered side-effect which compromises the quality of care, delays discharge and resumption of activities of daily living. ${ }^{1}$ Postoperative nausea and vomiting (PONV) is defined as nausea and/or vomiting occurring within 24 hours after surgery The incidence of vomiting and nausea in the postoperative period is about $30 \%$ and $50 \%$ respectively, whereas in a subset of high risk patients i.e. female gender, non-smoker, positive history of motion sickness or PONV, younger age, history of migraine, the incidence may be as high as $80 \% .1,2$ Post-operative nausea and vomiting can be classified as either early PONV (0-2 hours) or delayed PONV (2-24 hours). ${ }^{3}$ PONV has a complex and multifactorial aetiology, but there are a number of recognised contributing factors. These include patient, anaesthetic, surgical and postoperative conditions. ${ }^{4}$ Although, a number of pharmacological agents have been used to prevent PONV namely antihistaminics, phenothiazine derivatives, anti-cholinergic drugs, dopamine receptor antagonists and they have been associated with undesirable side effects like overt sedation, dysphoria and extra-pyramidal reactions. ${ }^{5}$

The introduction of $5-\mathrm{HT}_{3}$ receptor antagonist was heralded as a major advancement in the treatment of PONV owing to the absence of adverse effects observed with traditional anti-emetics. Ondansetron was the first clinically used $5-\mathrm{HT}_{3}$ receptor antagonist that was widely used but had a relatively short half-life of 3-5 hours. ${ }^{6}$ Granisetron is a more selective $5-\mathrm{HT}_{3}$ receptor antagonist and prophylactic use of this drug is effective for prevention of intraoperative and postoperative nausea and vomiting without serious adverse effects. ${ }^{5}$ Palonosetron has unique chemical structure; the interaction pattern with the $5-\mathrm{HT}_{3}$ receptor is different from earlier $5-\mathrm{HT}_{3}$ receptor antagonists with additional allosteric site binding property and an extended in-vivo plasma elimination half-life, thus requiring one-time dosage in 24 hours. ${ }^{6}$ Recent receptor binding studies suggest that it is further differentiated from other $5-\mathrm{HT}_{3}$ receptor antagonists by interacting with $5-\mathrm{HT}_{3}$ receptors in an allosteric, positively cooperative manner at sites different from those that bind with ondansetron and granisetron. This sort of receptor interaction may be associated with long lasting effects on receptor ligand binding and functional responses to serotonin. ${ }^{7}$

Laparoscopic surgeries have rapidly emerged as an alternative to open surgeries and are routinely performed procedures but a high incidence of PONV (50-70\%) has been reported in patients undergoing these procedures. Thus, prevention of PONV is of paramount important for the overall well- being of the patient in the post-operative phase.

\section{METHODS}

After obtaining approval from the Institutional Ethical committee, this prospective, randomized double blind study was conducted in a total of 135 cases of American Society of Anaesthesiologists physical status I-II, aged 18-65 years of either gender, scheduled for elective laparoscopic surgeries under general anaesthesia. Inclusion and exclusion criteria were made. Patients who refused to participate in the study, pregnant and lactating females, morbid obesity (BMI $>40$ $\mathrm{Kg} / \mathrm{m}^{2}$ ), allergy to any of the anti-emetic drugs, history of PONV and motion sickness, use of high dose opioids prior to surgery, history of endocrine or metabolic disorders, hepatorenal disease, gastrointestinal disorders and psychiatric diseases were excluded from the study. Sample size was calculated using software nMaster 2.0 at $\alpha$-error of $5 \%$ and $90 \%$ power. The sample size of 40 patients per group was required but considering an attrition rate of 5 cases per group a sample size of 45 cases per group was selected for better validation of our results.

The cases were randomized using sealed envelopes technique into three groups namely group 0 received Inj. Ondansetron $8 \mathrm{mg}$ I.V. group $\mathrm{P}$ received Inj. Palonosetron $0.075 \mathrm{mg}$ I.V. and group G received Inj. Granisetron $2.5 \mathrm{mg}$ I.V. After checking all anaesthesia prerequisites and valid informed consent, on the morning of surgery, patients were shifted to the operating room \& monitors (ECG, pulse oximetry, NIBP) were attached as per American Society of Anaesthesiologists (ASA) standards. Patients were premedicated with Inj. midazolam $1 \mathrm{mg}$ I.V. Inj. glycopyrrolate $0.2 \mathrm{mg}$ I.V. and Inj. fentanyl $2 \mu \mathrm{g} / \mathrm{Kg}$ I.V. The study medication was given to patient, $5 \mathrm{~min}$ prior to induction of general anaesthesia as per group allocation.

After preoxygenation for 3 minutes, induction of anaesthesia was done with Inj. thiopentone sodium $5 \mathrm{mg} / \mathrm{Kg}$ I.V. and Inj. vecuronium bromide $0.1 \mathrm{mg} / \mathrm{Kg}$ I.V. was administered to facilitate endotracheal intubation. Nasogastric tube was inserted to keep the stomach empty of air and other contents. Patients were mechanically ventilated and maintained with a gas-mixture of nitrous oxide and oxygen (2:1) with isoflurane and intermittent doses of vecuronium bromide. Intra-operatively, end tidal carbon dioxide was maintained between $35-40 \mathrm{mmHg}$ and intraabdominal pressure between 10-14 mm Hg. Intraoperative heart rate, systolic blood pressure, and diastolic blood pressure were maintained within $20 \%$ of baseline value. The patients were extubated after adequate respiration and after following verbal commands. Inj. Diclofenac sodium 1.5 $\mathrm{mg} / \mathrm{Kg}$ I.V. was administered after extubation for postoperative analgesia. Postoperatively, the patients were assessed at $2 \mathrm{hrs}, 6 \mathrm{hrs}, 12 \mathrm{hrs}$ and $24 \mathrm{hrs}$ for vital parameters, nausea and vomiting, any adverse effects, need of rescue medication and patient satisfaction score. The episodes of nausea and emesis were recorded by a separate observer who was blinded to the type of antiemetic that was given prophylactically to the patients. Incidences of nausea was scored on an 11-point verbal rating scale (VRS) from 0 (no nausea) to 10 (worst possible nausea). Severity was scored according to Verbal Rating Scale $(0=$ no nausea, $1-3=$ mild nausea, 4-6 $=$ moderate nausea, $7-10=$ severe nausea). The emetic episodes were compared using PONV score $(0=$ No nausea and vomiting, 1=Nausea only, 2=Vomiting once, $3=$ Vomiting more than once). Inj. Metoclopramide $10 \mathrm{mg}$ intravenously was given as rescue antiemetic if VRS score was $>4$ or on patient's request. The frequency of rescue medication required over 24 hrs post operatively was noted. Other side effects like bradycardia, hypotension, headache, dizziness, and constipation were also recorded in all groups and any untoward event requiring active intervention was managed accordingly. 
The degree of overall satisfaction with management of nausea and vomiting was evaluated at the end of observation period (24 hrs) using Patient Satisfaction Score (grade $0=$ poor, grade $1=$ adequate, grade $2=$ good, grade $3=$ excellent). ${ }^{5}$

\section{Statistical Analysis}

Data was entered in Microsoft excel spreadsheet and checked for errors and thereafter analysed using SPSS (statistical package for social sciences) for Windows, version 17.0 (Chicago: SPSS Inc). Pearson's Chi-square test was used to evaluate differences between groups for categorized variables. Normally distributed data were presented as means and standard deviation, or $95 \%$ confidence intervals. For normally distributed two groups having quantitative data, independent sample t-test was employed and for nonnormal data, Mann Whitney $U$ test was used. Analysis of Variance (ANOVA) was applied for three or more normally distributed quantitative data and Kruskal Wallis $\mathrm{H}$ test used in case of normality violation. All tests were performed at a $5 \%$ level significance.

\section{RESULTS}

Our clinical study comprised of 135 patients of ASA physical status I \& II posted for elective laparoscopic surgeries under general anaesthesia to compare the effectiveness of palonosetron and granisetron over ondansetron for postoperative nausea and vomiting during 24-hour (hr) period. The three groups were statistically comparable in terms of demographic characteristics namely age, sex, ASA status and duration of anaesthesia and surgery, as shown in [table 1].

\begin{tabular}{|c|c|c|c|c|}
\hline Variables & Granisetron & Ondansetron & Palonosetron & p-Value \\
\hline Age & $43.17 \pm 16.08$ & $39.88 \pm 13.80$ & $43.88 \pm 12.72$ & 0.369 \\
\hline Gender (M/F) & $5 / 40$ & $11 / 34$ & $9 / 36$ & 0.253 \\
\hline ASA grade (I/II) & $29 / 16$ & $32 / 13$ & $30 / 15$ & 0.790 \\
\hline Table 1. Demographical Profile of Patients across the Three Groups \\
\hline
\end{tabular}

The hemodynamic parameters (HR, SBP, DBP, MAP) studied during the intraoperative and postoperative periods were not statistically significant in between the groups. ( $>>0.05$ ) Complete response to the study drug i.e (no nausea and vomiting) was seen in $73.3 \%$ patients in group G, $80 \%$ patients in group 0 and $95.6 \%$ patients in group $P(p=0.016)$, which was statistically significant. [table 2] The overall incidence of nausea in $24 \mathrm{hr}$ period with a PONV score of 1 was more in ondansetron and granisetron group than palonosetron group. This difference was statistically significant $(\mathrm{p}=0.037)$. [table 2]

The PONV Score of 2 with single emetic episode over 24 $\mathrm{hr}$ observational period was observed in only 3 patients in palonosetron group whereas 10 patients in ondansetron group and 11 patients in granisetron group $(\mathrm{p}=0.056)$, which was statistically significant. [table 2] The incidence of postoperative vomiting more than once in 24 hrs observational period (PONV Score 3) was found to be statistically significant with $20 \%$ incidence in patients group 0 and $17.8 \%$ in group $\mathrm{G}$ and $2.2 \%$ in group $\mathrm{P}(\mathrm{p}=0.313)$. [table 2]

\begin{tabular}{|c|c|c|c|c|}
\hline 方 & 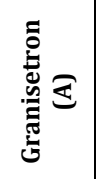 & 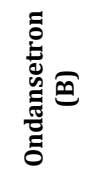 & 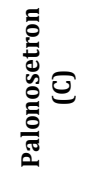 & 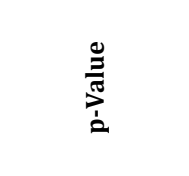 \\
\hline $\begin{array}{l}\text { Complete response No nausea } \\
\text { and vomiting }\end{array}$ & $\begin{array}{c}33 \\
(73.3 \%)\end{array}$ & $\begin{array}{c}36 \\
(80 \%)\end{array}$ & $\begin{array}{c}43 \\
(95.6 \%)\end{array}$ & 0.016 (Significant) \\
\hline $\begin{array}{l}\text { PONV Score } 1 \text { Incidence of } \\
\text { Nausea in } 24 \text { hrs. }\end{array}$ & $\begin{array}{c}8 \\
(17.8 \%)\end{array}$ & $\begin{array}{c}8 \\
(17.8 \%)\end{array}$ & $\begin{array}{c}1 \\
(2.2 \%)\end{array}$ & 0.037 (Significant) \\
\hline $\begin{array}{l}\text { PONV Score } 2 \text { Incidence of } \\
\text { Vomiting once in } 24 \mathrm{hrs} \text {. }\end{array}$ & $\begin{array}{c}11 \\
(24.4 \%) \\
\end{array}$ & $\begin{array}{c}10 \\
(22.2 \%) \\
\end{array}$ & $\begin{array}{c}3 \\
(6.7 \%) \\
\end{array}$ & 0.048 (Significant) \\
\hline $\begin{array}{c}\text { PONV Score } 3 \text { Incidence of } \\
\text { Vomiting more than once in } 24 \\
\text { hrs. }\end{array}$ & $\begin{array}{c}8 \\
(17.8 \%)\end{array}$ & $\begin{array}{c}9 \\
(20 \%)\end{array}$ & $\begin{array}{c}1 \\
(2.2 \%)\end{array}$ & 0.026 (Significant) \\
\hline
\end{tabular}

Table 2. Comparison of Incidence in $1^{\text {st }} 24$ Hrs. amongst Study Groups

\begin{tabular}{|c|c|c|c|c|c|c|}
\hline 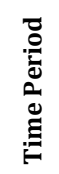 & 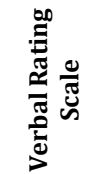 & 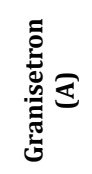 & 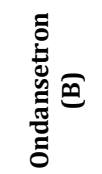 & 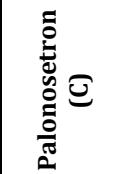 & 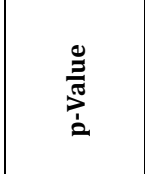 & 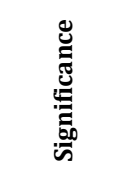 \\
\hline \multirow{2}{*}{$\begin{array}{l}0-24 \\
\text { hour }\end{array}$} & \multirow{2}{*}{$\begin{array}{l}\text { Complete } \\
\text { response }\end{array}$} & \multirow{2}{*}{$\begin{array}{c}35 \\
(77.7 \%)\end{array}$} & \multirow{2}{*}{$36(80 \%)$} & \multirow{2}{*}{$43(95.5 \%)$} & $\begin{array}{l}\mathrm{A}-\mathrm{C}=\mathrm{p}<0.01 \\
\mathrm{~B}-\mathrm{C}=\mathrm{p}<0.01 \\
\end{array}$ & Significant \\
\hline & & & & & $A-B=p \sim 0.790$ & $\begin{array}{c}\text { Non- } \\
\text { Significant }\end{array}$ \\
\hline \multicolumn{7}{|c|}{$\begin{array}{l}\text { Table 3. Comparison of Verbal Rating Scale in } \\
\text { amongst all the Study Groups }\end{array}$} \\
\hline
\end{tabular}

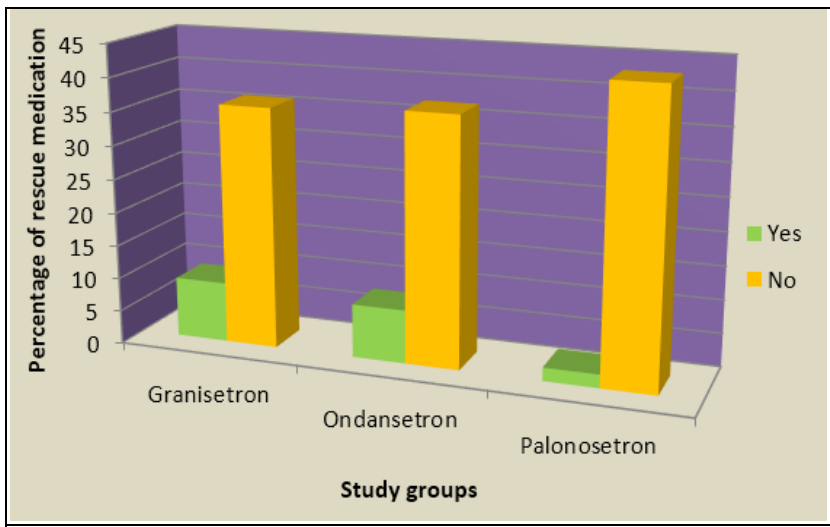

Figure 1. Requirement of Rescue Medication amongst the Three Drugs

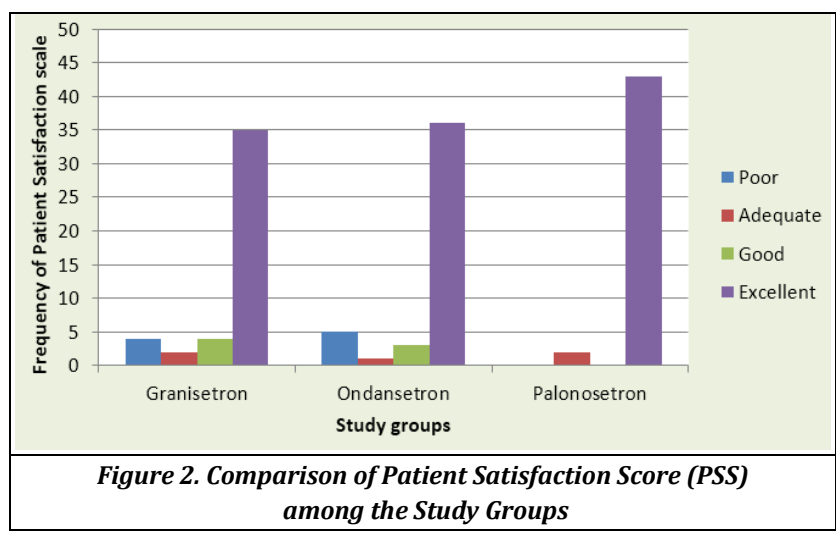

A higher incidence of nausea as well as vomiting was observed in patients of Group Ondansetron and Granisetron than Palonosetron. A verbal rating scale score was used to measure the incidence of severity of nausea after the surgery. The complete response (no nausea) in 0-24 hr time interval was seen in 43 patients in Palonosetron group while Granisetron had complete response in 35 patients and Ondansetron had complete response in 36 patients. Nausea followed by vomiting was treated with rescue anti-emetic, but nausea alone was not given any treatment [Table 3]. 
Rescue antiemetic was given in 8 patients $(17.7 \%)$ in group 0 and 9 patients (20\%) in group G whereas only 2 patients $(4.4 \%)$ required rescue anti-emetic in group $P$, which was statistically significant. [fig. 1]. Patient satisfaction score measured at the end of 24 hours showed a significant difference between the three groups ( $p \sim 0.041$ ) [fig.2]. The adverse effects were recorded and were found to be statistically insignificant when compared among all the three groups.

\section{DISCUSSION}

Post-operative nausea and vomiting (PONV) is one of the major complaint of patients undergoing laparoscopic surgery under general anaesthesia. Although, it is self-limiting, a delayed wound healing and increased hospital stays has been attributed to it. The high incidence of PONV following laparoscopic surgeries under general anaesthesia justifies the use of prophylactic anti-emetic therapy. The factors which increase the incidence of PONV include age, gender, obesity, history of motion sickness, perioperative use of opioids, anaesthetic technique, duration and type of the surgical procedure and severity of post-operative pain. Numerous drugs have been used in the past for the prevention of postoperative nausea and vomiting, but were associated with undesirable side effects. The $5-\mathrm{HT}_{3}$ antagonists are found to be effective in preventing post-operative nausea and vomiting without any significant side effects. ${ }^{8}$

The present study was undertaken to evaluate and compare the effects of prophylactically administered ondansetron, palonosetron and granisetron intravenously in patients undergoing elective laparoscopic surgeries for control of post-operative nausea and vomiting. Other objectives included comparison of side effects profile, use of rescue anti-emetic and patient satisfaction scores in all the three groups. There was no statistical difference in the patients in all the three groups namely group 0 (Ondansetron), group $P$ (palonosetron) and group G (granisetron) in terms of demographic factors (age, sex, duration of surgery) and ASA Grading. The anaesthetic technique was standardized (general anaesthesia with endotracheal intubation and controlled ventilation) in all patients.

Many studies have been conducted on the dose and use of ondansetron for preventing PONV. Whereas a few clinical studies recommend $4 \mathrm{mg}$ or $8 \mathrm{mg}$, a meta-analysis done by Ryu et al. suggested that $8 \mathrm{mg}$ was optimal and more effective than $4 \mathrm{mg}$ for the control of nausea and vomiting following surgeries. ${ }^{9}$ Therefore, we selected ondansetron $8 \mathrm{mg}$ for our study. In our study, we chose the dose of palonosetron to be $0.075 \mathrm{mg}$, since the study done by Candiotti $\mathrm{K}$ et al concluded that $0.0075 \mathrm{mg}$ of palonosetron effectively reduced the incidence of PONV when compared to $0.025 \mathrm{mg}$ and 0.050 mg. ${ }^{10}$ Kovac et al. also found that palonosetron $75 \mu \mathrm{g}$ was more effective than placebo in the $72 \mathrm{hr}$ post-operative period in female patients undergoing elective gynaecological and breast surgery. ${ }^{11}$

The dose of granisetron $2.5 \mathrm{mg}$ selected for this study was within its effective dose range $(40-80 \mu \mathrm{g} / \mathrm{Kg})$. Fuji et al. demonstrated that granisetron is superior to metoclopramide in prevention of PONV after general anaesthesia, and optimum antiemetic dose is $40 \mu \mathrm{g} / \mathrm{Kg}{ }^{12}$ Post-Operative Nausea Vomiting (PONV) score was used to measure the incidence of vomiting across various time periods i.e. $2 \mathrm{hrs}, 6$ hrs, $12 \mathrm{hrs}$ and $24 \mathrm{hrs}$. A significant difference in the PONV score was observed among the three study groups with palonosetron group having less incidence of nausea and vomiting as compared to the other two groups. The number of complete responders were also more in palonosetron group $(\mathrm{p}<0.05)$. The PONV score used was similar to that used by Taninder et al in a study conducted in 2014.6

Taninder Singh et al found the overall incidence of postoperative nausea (PONV Score 1) in 24 hrs. was $56.66 \%$ in patients among group Ondansetron group and $30 \%$ in patients of Palonosetron group. The incidence of PONV was higher in ondansetron group and the difference between two groups was statistically significant $(p=0.037)$ They also concluded that prophylactic administration palonosetron $0.075 \mathrm{mg}$ I.V. is more effective than ondansetron $8 \mathrm{mg} \mathrm{I.V.} \mathrm{in}$ preventing the incidence and severity of post-operative nausea and vomiting in patients undergoing middle ear surgeries under general anaesthesia.

Our results are in concordance with the study done by Bhattacharjee et $\mathrm{al}^{13}$ who conducted a comparative study between palonosetron $(75 \mu \mathrm{g})$ and granisetron $(2.5 \mathrm{mg})$ to prevent postoperative nausea and vomiting after laparoscopic cholecystectomy. They concluded that prophylactic therapy with palonosetron is more effective than granisetron for long term prevention of postoperative nausea and vomiting after laparoscopic cholecystectomy. The Verbal Rating Scale score was used to assess the severity of nausea across various time periods which was statistically significant $(\mathrm{p}<0.05)$. Similar observations were noted in studies conducted by Bhalla Jyoti et $\mathrm{al}^{14}$ and Shadangi BK et $\mathrm{al}^{15}$ and Moon YE et al. ${ }^{16}$

Rescue anti-emetic was administered with the intention to treat the patients as post-operatively episodes of vomiting are very much distressing to the patient. It has been recommended that in cases of breakthrough PONV, repeat anti-emetic should be of the different class that the one used in prophylaxis. ${ }^{17}$ For this reason, metoclopramide was used as rescue anti-emetic. Requirement of rescue anti-emetic was $20 \% \quad(n=9)$ in Granisetron group; $17.7 \% \quad(n=8)$ in Ondansetron group and $4.44 \%(\mathrm{n}=2)$ in palonosetron group. The requirement of rescue medication was least when palonosetron was used for prophylaxis when compared to other two drugs. Palonosetron had the lowest incidence of adverse effects among the three study groups, however, there was no significant difference in the occurrence of these adverse effects among the study groups $(p>0.05)$. These findings are in concordance with Laha et $\mathrm{al}^{18}$ and Solanki et $\mathrm{al}^{19}$ and Rao JS et al. ${ }^{8}$

A patient satisfaction score with a grading $0-4$ for the evaluation of patient satisfaction was used in all the three groups. The satisfaction score was found to be highest in palonosetron group in our study. Satisfaction score in other groups was less than that in palonosetron group, but were comparable. In the present study, we did not include any control group receiving placebo as PONV is not controlled by placebo. Moreover, delay in treatment in face of any untoward event may worsen the patient outcome. The sample size was small and as study was performed in a small 
geographic location, the results of this study may not be representative of population in different geographic locations. Future researches can be done using newer $5-\mathrm{HT}_{3}$ receptor antagonists including the tropisetron, alosetron and dolasetron for effective management of PONV.

\section{CONCLUSIONS}

Palonosetron is better than granisetron and ondansetron for the prophylaxis of post-operative nausea and vomiting in patients undergoing laparoscopic procedures under general anaesthesia. It not only provides higher levels of satisfaction to patients but also has a safer profile with minimal side effects. Moreover, use of palonosetron is associated with less frequent dosing intervals as compared to other two $5-\mathrm{HT}_{3}$ receptor blockers.

\section{REFERENCES}

[1] Öbrink E, Jildenstål P, Oddby E, et al. Post-operative nausea and vomiting: update on predicting the probability and ways to minimize its occurrence, with focus on ambulatory surgery. Int J Surg 2015;15:100-6.

[2] Gan TJ, Diemunsch P, Habib AS, et al. Consensus guidelines for the management of postoperative nausea and vomiting. Anesth Analg 2014;118(1):85-113.

[3] Bergese SD, Puente EG, Antor MA, et al. The effect of a combination treatment using palonosetron, promethazine and dexamethasone on the prophylaxis of postoperative nausea and vomiting and QTc interval duration in patients undergoing craniotomy under general anesthesia: a pilot study. Front Med (Lausanne) 2016;3:1.

[4] Kenny GN. Risk factors for postoperative nausea and vomiting. Anaesthesia 1994;Suppl 49:6-10.

[5] Naik R, Thakur R, Sahare KK, et al. Intravenous ramosetron and granisetron for prevention of postoperative nausea and vomiting in patients undergoing elective caesarean section. A comparative study. Journal of Science 2015;5(10):930-4.

[6] Singh T, Shah N, Patel C, et al. A comparative study of prophylactic ondansetron versus palonosetron for postoperative nausea and vomiting in middle ear surgeries. Int J Biomed Adv Res 2014;5(12):619-22.

[7] Gugale AA, Bhalerao PM. Palonosetron and granisetron in postoperative nausea vomiting: a randomized doubleblind prospective study. Anesth Essays Res 2016;10(3):402-7.
[8] Rao JS, Geetha C, Naik RP. Comparison of palonosetron with ondansetron for prevention of nausea and vomiting during postoperative period in patients undergoing ENT surgeries. Int J Contemp Med Res 2017;4(7):1486-9.

[9] Ryu J, So YM, Hwang J, et al. Ramosetron versus ondansetron for the prevention of postoperative nausea and vomiting after laparoscopic cholecystectomy. Surg Endosc 2010;24(4):812-7.

[10] Candiotti KA, Kovac AL, Melson TI, et al. A randomized, double-blind study to evaluate the efficacy and safety of three different doses of palonosetron versus placebo for preventing postoperative nausea and vomiting. Anesth Analg 2008;107(2):445-51.

[11] Kovac AL, Eberhart L, Kotarski J, et al. A randomized, double-blind study to evaluate the efficacy and safety of three different doses of palonosetron versus placebo in preventing postoperative nausea and vomiting over a 72-hour period. Anesth Analg 2008;107(2):439-44.

[12] Fuji Y, Tanaka H, Toyooka H. Optimal antiemetic dose of granisetron for prevention of post-operative nausea and vomiting. Can J Anaesth 1994;41(9):794-7.

[13] Bhattacharjee DP, Dawn S, Nayak S, et al. A comparative study between palonosetron and granisetron to prevent postoperative nausea and vomiting after laparoscopic cholecystectomy. J Anaesthesiol Clin Pharmacol 2010;26(4):480-3.

[14] Bhalla J, Baduni N, Bansal P. Comparison of palanosetron with ondansetron for postoperative nausea and vomiting in patients undergoing laparoscopic cholecystectomy under general anesthesia. J Minim Access Surg 2015;11(3):193-7.

[15] Shadangi BK, Agarwal J, Pandey R, et al. A prospective, randomized, double-blind, comparative study of the efficacy of intravenous ondansetron and palonosetron for prevention of postoperative nausea and vomiting. Anaesth Pain Intensive Care 2013;17(1):55-8.

[16] Moon YE, Joo J, Kim JE, et al. Anti-emetic effect of ondansetron and palonosetron in thyroidectomy: a prospective, randomized, double-blind study. $\mathrm{Br} \mathrm{J}$ Anaesth 2012;108(3):417-22.

[17] White PF, Watcha MF. Postoperative nausea and vomiting: prophylaxis versus treatment. Anesth Analg 1999;89(6):1337-9.

[18] Laha B, Hazra A, Mallick S. Evaluation of antiemetic effect of intravenous palonosetron versus intravenous ondansetron in laparoscopic cholecystectomy: a randomized controlled trial. Indian J Pharmacol 2013;45(1):24-9.

[19] Solanki R, Gosai N, Jha RK, et al. A comparative study between palonosetron hydrochloride and granisetron hydrochloride to prevent postoperative nausea and vomiting after gynaecological surgery. Int J Biomed Adv Res 